\title{
Correction to: Hyperbaric oxygen attenuates neuropathic pain and reverses inflammatory signaling likely via the Kindlin-1/Wnt-10a signaling pathway in the chronic pain injury model in rats
}

Baisong Zhao, Yongying Pan, Haiping Xu and Xingrong Song*

Correction to: J Headache Pain 18, 1 (2017)

https://doi.org/10.1186/s10194-016-0713-y

Following the publication of the original article [1], we were notified of an error in Fig. 2.

The authors have now provided the correct Fig. 2 (which can be found below) and apologize for the mistake.

Published online: 04 March 2022

\section{Reference}

1. Zhao et al (2017) Hyperbaric oxygen attenuates neuropathic pain and reverses inflammatory signaling likely via the Kindlin-1/Wnt-10a signaling pathway in the chronic pain injury model in rats. J Headache Pain. 18:1. https://doi.org/10.1186/s10194-016-0713-y original author(s) and the source, provide a link to the Creative Commons licence, and indicate if changes were made. The images or other third party material in this article are included in the article's Creative Commons licence, unless indicated otherwise in a credit line to the material. If material is not included in the article's Creative Commons licence and your intended use is not permitted by statutory regulation or exceeds the permitted use, you will need to obtain permission directly from the copyright holder. To view a copy of this licence, visit http://creativecommons.org/licenses/by/4.0/. The Creative Commons Public Domain Dedication waiver (http://creativeco mmons.org/publicdomain/zero/1.0/) applies to the data made available in this article, unless otherwise stated in a credit line to the data. 


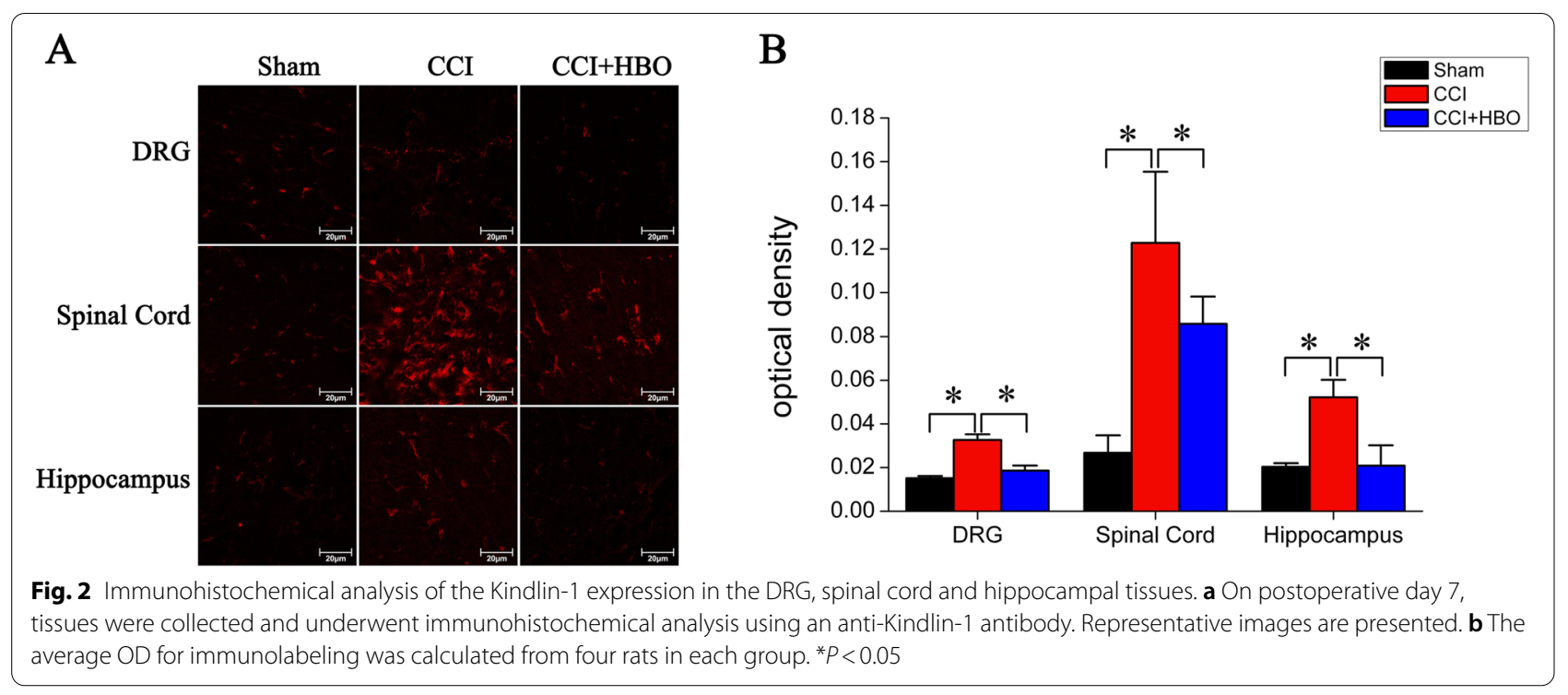

